\title{
Farmers Participatory Evaluation of Chickpea Varieties in Mirab Badwacho and Damot Fullasa Districts of Southern Ethiopia Yasin Goa ${ }^{*}$, Demelash Bassa', Genene Gezahagn' ${ }^{1}$ and Mekasha Chichaybelew² \\ ${ }^{1}$ Areka Agricultural Research Center, SARI, Ethiopia \\ ${ }^{2}$ Debrezeit Agricultural Research Center, EIAR, Ethiopia
}

\begin{abstract}
Chickpea is one of the grain food legumes contributing an enormous amount of protein to the human diet in Southern Ethiopia. Though a lot of improved varieties were released by research centers farmers depend on low yield and local varieties. Hence, participatory variety selection is one of the methods used to evaluate varieties through involvement of users. Participatory Variety Selection (PVS) were conducted during 2015/2016 in Mirab Badwacho and Damot Fullasa districts of South region, Ethiopia to assess the performance of chickpea (Cicer arietinum $\mathrm{L}$.) varieties and to evaluate farmers' selection criteria for chickpea. Six improved varieties with local check were laid out in a randomized complete block design with four replications. Significant variation among chickpea varieties were observed for most the agronomic traits collected except for number of pod per plant which was not significant. Concerning location, the majority of the traits were showed significant difference indicating dissimilarity in agro ecologies of the two districts. The study also revealed that in some cases the researchers' selection match with farmers' preferences. However, in general farmers have shown their own way of selecting a variety for their localities. These parameters include earliness, diseases and pest resistance, seed colour, branch number and length and seed size. Hence, including farmers' preferences in a variety selection process is a paramount important. Therefore, based on attentively measured parameters, farmers' favourites and the agro ecologies of the site the varieties Natoli, Dalota and Arerti are selected for the area. The varieties Habru and Ejere should also be given due consideration by farmers for its earlier maturity in the study area.
\end{abstract}

Keywords: Chickpea; Variety selection; Participatory; Farmers' preferences; Grain yield

\section{Introduction}

Chickpea (Cicer arietinum L.) is the third most important pulse crop with a total annual global production of $9.7 \mathrm{M}$ tones from 11.5 Mha [1]. According to FAOSTAT [2], the global chickpea area was 12.0 million ha, production was 10.9 million metric tons and yield was 913 $\mathrm{kg} \mathrm{ha}^{-1}$ in 2010 . India is the largest chickpea producing country, with $68 \%$ of world chickpea production. The other major chickpea producing countries include Ethiopia, Australia, Pakistan, Turkey, Myanmar, Iran, Mexico, Canada, and USA. In Ethiopia, chickpea is mainly grown at an altitude of 1400-2300 m.a.s.l., where annual rainfall ranges between 700 and $2000 \mathrm{~mm}$ [3]. It is the major cool season food legumes ranked second next to Faba bean, which occupies about 239,747.51 hectares of land annually with estimated production of $4,586,822.55$ quintals. The national average seed yield is $19.13 \mathrm{qt} / \mathrm{ha}$ [4]. Two types of chickpea; Kabuli type is grown in temperate regions while the desi type chickpea is grown in the semi-arid tropics. Ethiopia has suitable agro-climatic conditions for the production of both types of chickpeas. Whereas, in the country Desi type chickpeas has traditionally grown for both home consumption and sale. Currently, the Kabuli types are just beginning to expand in Ethiopia as well as in southern region.

Chickpea seeds are eaten fresh as green vegetables, parched, fried, roasted, and boiled and it is valued for its nutritive seeds with high protein content, 25.3-28.9\%, after dehulling [5]. Chickpea seed has 38$59 \%$ carbohydrate, $3 \%$ fiber, $4.8-5.5 \%$ oil, $3 \%$ ash, $0.2 \%$ calcium, and $0.3 \%$ phosphorus [5].

In Ethiopia smallholder farmers grow chickpea at the end of the main rainy season using residual soil moisture because of its ability to withstand drought stress. Through efficient use of the residual moisture, chickpea also allows farmers to harvest two crops in a growing season (cereal followed by chickpea), improving their food supply, and secure an additional source of income. Similarly, in southern Nations, Nationalities, and Peoples Regional State (SNNPRS), chick pea is occupying about $5,662.23$ hectares of land annually with estimated production of $93,892.80$ quintals [4].

Despite its importance, the national (19.13 qt/ha) as well as regional average yields ( $16.58 \mathrm{qt} / \mathrm{ha}$ ) of chickpea are low due to various production constraints including: Low yield potential of landraces, lack of superior varieties, their susceptibility to biotic and a biotic stresses and poor cultural practices are some the serious constraints in chickpea production in Ethiopia [6-8]. Chickpea varieties were released by the various national and regional research centers of the country. Farmers have no ample information about the released varieties because they were released with poor involvement of farmers and the released varieties had not yet tested in the study area. In the country, efforts have been made through PVS to develop and popularize improved varieties of some crops. Participatory approach is being carried out in many crops like bread wheat [9], common bean [10] and maize [11]. Danial et al. [12] reported that farmer's preferences vary with environmental conditions, traits of interest, ease of cultural practice, processing, use and marketability of the product, ceremonial and religious values. However, the farmers' selection criteria for improved

*Corresponding author: Yasin Goa, Areka Agricultural Research center, SARI, Ethiopia, Tel: +251912135281; E-mail: yasingoac76@yahoo.com

Received December 22, 2016; Accepted January 04, 2017; Published January 11, 2017

Citation: Goa Y, Bassa D, Gezahagn G, Chichaybelew M (2017) Farmers Participatory Evaluation of Chickpea Varieties in Mirab Badwacho and Damot Fullasa Districts of Southern Ethiopia. Hydrol Current Res 8: 264. doi: 10.4172/2157-7587.1000264

Copyright: (c) 2017 Goa Y, et al. This is an open-access article distributed under the terms of the Creative Commons Attribution License, which permits unrestricted use, distribution, and reproduction in any medium, provided the original author and source are credited. 
chickpea varieties were not adequately assessed and well documented especially in the Southern parts of Ethiopia. Therefore, the objectives of this study were to evaluate the performance of the released chickpea varieties through PVS and to assess farmers' selection criteria for future chickpea improvement work with the participation of farmers in Southern Ethiopia [13].

\section{Materials and Methods}

The trial was conducted during 2015/2016 main cropping season at two districts (Mirab Badewacho and Damot Fullasa) in Southern Ethiopia. Geographically, Mirab Badewacho (Woybra kebele) is found at $37^{\circ} 51^{\prime}$ E Longitude and N $7^{\circ} 08$ Latitude and at 1899 , whereas Damot Fullasa (Shanto Zuria kebele) is found at $37^{\circ} 51^{\prime}$ E Longitude and $07^{\circ} 00^{\prime}$ $\mathrm{N}$ Latitude and at an altitude of $1922 \mathrm{~m}$ above sea level. The chickpea varieties used in the trials at two districts were Habru, Arerti, Natoli, Ejere, Dalota and farmers' varieties. Six varieties including the local checks were tested in the study. The trials were planted by farmers in collaboration with researchers and the agricultural extension workers in RCBD with four replications. Each farmer acted as a replicate. Each experimental plot had an area of $10 \times 10 \mathrm{~m}\left(100 \mathrm{~m}^{2}\right)$. Each plot comprised of thirty three rows which were $10 \mathrm{~m}$ long. Spacing of $30 \mathrm{~cm}$ between rows and $10 \mathrm{~cm}$ between plants was used.

Farmers participated in the entire crop cultivation operations from sowing till harvesting. Technical advice on management practice of the improved chickpea varieties was given by the researchers. Weeding, spraying such as karate/malathion against insect pests (pod borer) was done as required. Trials were managed according to recommended agronomic practices. Farmers were participated in evaluation and selection of improved chickpea varieties at pod filling and maturity stage through organizing field days. Farmers, higher officials, researchers, and extension personnel were participated in field day. Such field days were beneficial for participating farmers in comparing the varieties when they are in the field and an opportunity for research and extension work to point out the differences. Conducting field day at the maturity and harvest time were more vital in evaluating the yield potential and other yield contributing attributes. Farmers set their selection criteria and ranking of varieties according to their setting criteria. The rank sum method each trait for each variety was used to rank varieties based on farmers' selection criteria. The value of each trait has equal weight. Data were collected on plant height, number of pod per plant, number of days to maturity, biomass yield and grain yield per hectare. The data was subjected to Analysis of Variance (ANOVA) using the Statistical Analysis System (SAS). Means were separated using the Least Significant Difference (LSD) at $\mathrm{P}=0.05$.

\section{Results and Discussions}

The Participatory Variety Selection (PVS) ensured farmers to be participant in selection of improved chickpea crop varieties in comparison with local check based on their preference criteria.

\section{Researchers' evaluation}

Combined analyses of data from the two trial sites (Mirab Badwacho and Damot Fullasa) shown very highly significant varietal differences $(\mathrm{P}<0.01)$ in grain yield, days to $95 \%$ maturity and biomass yield (Table 1). Table 1 shows mean square-values of researchers' evaluation of agronomic trait for the varieties, locations, and error. Researchers evaluated the varieties based on yield and other agronomic traits. The varieties revealed highly significant to significant variation in all agronomic traits recorded except number of pod per plant. With regard to locations, most of the agronomic traits recorded shows statistically significant. This indicates that all the varieties responded not similarly to the tested locations.

Table 2 indicates researchers' evaluation of the average values of the different agronomic traits. The average data showed that chickpea varieties differs in days to maturity, biomass yield $(\mathrm{kg} / \mathrm{ha})$ and grain yield $(\mathrm{kg} / \mathrm{ha})$. However, the varieties did not vary in number of pod per plant.

The study revealed that chickpea varieties highly significantly differ in biomass yield ( $\mathrm{kg} / \mathrm{ha})$ and grain yield ( $\mathrm{kg} / \mathrm{ha})$ of plant (Table 2). The variety Natoli had the highest grain yield $\left(1837.5 \mathrm{~kg} \cdot \mathrm{ha}^{-1}\right)$, while local check had the lowest grain yield (1075.5 kg.ha $\left.{ }^{-1}\right)$. Variation in environment and in their genetic makeup could be the possible reason for the observed differences in chickpea varieties. These findings are in line with those of Biru et al. [7], who tested different improved chickpea varieties and reported that average grain yield over environments varied from 520-2010 kg.ha ${ }^{-1}$. From the varieties evaluated, Ejere had maximum biomass yield ( $5425 \mathrm{~kg} / \mathrm{ha}$ ) next by varieties Arerti and Natoli with the biomass yield of $5337.5 \mathrm{~kg} / \mathrm{ha}$ and $5118.8 \mathrm{~kg} / \mathrm{ha}$, respectively.

Mean values were differing significantly for plant height of test varieties and local check (Table 2). The highest plant was observed in Ejere $(58.68 \mathrm{~cm})$ followed by Dalota and Natoli with height of $58.3 \mathrm{~cm}$ and $57.97 \mathrm{~cm}$ respectively. The past research work reported by Biru et al. [7] regarding plant height in chickpea is agreement with the present investigation.

The data analysis of revealed significant variations among the evaluated varieties of chickpea for pod per plant (Table 2 ). The variety Arerti (86.33) had larger pod per plant, while local check (65.62) had smaller pod per plant. This is in line with Biru et al. [7] who stated that average pod per plant among four chickpea varieties varied from 37.5 to 83.6. According to the mean values Habru was earliest for days to maturity (102.75 days) followed by Ejere and local check with the values of 110.5 and 114.63 days, respectively. These results are similar to Biru et al. $[7,8]$, who also suggested significant genetic differences for this trait among chickpea genotypes.

\section{Farmers chickpea variety evaluation}

Representative farmers to the area and having long experience in farming of chickpea were selected to participate on trial evaluation. Before beginning of the selection process, selected farmers from the two villages were asked to set their priority selection criteria. Accordingly, earliness, Disease and pest resistance, Seed colour, Branch number and length, Seed size Ground cover, Emergence, Pod number, Seed number and yield were identified as the most important farmers' preference criteria.

Scale of $1-5$ were used for ranking of varieties, whereby 1 being very good and 5 being very poor. Table 3 showed the Damot Fullas districts farmers' selection of the varieties based on the criteria they fixed. Shanto Zuria village farmers (Table 3) varietal assessment showed that variety Arerti was ranked highest (1.4) followed by Ejere and Dalota with the values of 1.7 and 1.8. Accordingly, chickpea varieties such as Arerti, Ejere, Dalota, Habru, Natoli, and local were preferred at Damot Fullasa site as $1^{\text {st }}, 2^{\text {nd }}, 3^{\text {rd }}, 4^{\text {th }}, 5^{\text {th }}$ and $6^{\text {th }}$ respectively. Their grain yields were $2200 \mathrm{~kg} / \mathrm{ha}, 2175 \mathrm{~kg} / \mathrm{ha}, 1900 \mathrm{~kg} / \mathrm{ha}, 1875 \mathrm{~kg} / \mathrm{ha}, 1852.5 \mathrm{~kg} / \mathrm{ha}$ and $1325 \mathrm{~kg} / \mathrm{ha}$ of Natoli, Dalota, Arerti, Ejere, Habru and local check, respectively (Table 2 ). It can be said that improved chickpea varieties evaluated in this site were superior to local check and best adapted to specific environment and similar agro ecology provided that other 
Citation: Goa Y, Bassa D, Gezahagn G, Chichaybelew M (2017) Farmers Participatory Evaluation of Chickpea Varieties in Mirab Badwacho and Damot Fullasa Districts of Southern Ethiopia. Hydrol Current Res 8: 264. doi: 10.4172/2157-7587.1000264

Page 3 of 6

\begin{tabular}{|c|c|c|c|c|c|c|}
\hline \multirow{2}{*}{ Source of variation } & \multicolumn{5}{|c|}{ Mean square } \\
\hline Replication & DF & DM & PH (cm) & PP & BY (kg/ha) & GY (kg/ha) \\
\hline Varieties & 3 & $19.81 \mathrm{~ns}$ & $195.12^{*}$ & $2547.82^{* *}$ & $14158524.31^{* *}$ & $1289863.19^{* *}$ \\
\hline Location & 5 & $279.90^{* *}$ & $295.77^{*}$ & $572.79 \mathrm{~ns}$ & $6039302.08^{* *}$ & $617327.08^{* *}$ \\
\hline Loc variety & 1 & $1752.08^{* *}$ & $3512.34^{* *}$ & $26245.45^{* *}$ & $34256302.08^{* *}$ & $5076502.08^{* *}$ \\
\hline Rep (loc) & 5 & $69.433 \mathrm{~ns}$ & $21.67 \mathrm{~ns}$ & $890.08 \mathrm{~ns}$ & $1339302.08 \mathrm{~ns}$ & $16277.08 \mathrm{~ns}$ \\
\hline Error & 3 & $141.25 \mathrm{~ns}$ & $133.75 \mathrm{~ns}$ & $2058.31^{* *}$ & $12966857.64^{* *}$ & $1215002.08^{* *}$ \\
\hline CV (\%) & 30 & 19.98 & 50.74 & 174.94 & 804691 & 69940.97 \\
\hline LSD (0.05) & & 3.94 & 12.92 & 17.05 & 19.45 & 16.92 \\
\hline
\end{tabular}

Where, ${ }^{*}=$ Highly significant at $\mathrm{P} \leq 0.01 ;{ }^{*}=$ Significant at $\mathrm{P} \leq 0.05$; ns=Not significant at $\mathrm{P}=0.05$; $\mathrm{DM}=\mathrm{Days}$ to maturity; $\mathrm{PH}=\mathrm{Plant}$ height; $\mathrm{PP}=\mathrm{Pod}$ per plant; $\mathrm{BY}=\mathrm{Biomass}$ yield;

$\mathrm{GY}=$ Grain yield $(\mathrm{kg} / \mathrm{ha})$

Table 1: Yield and yield components of chickpea varieties mean square values of combined over location.

\begin{tabular}{|c|c|c|c|c|c|c|c|}
\hline Varieties & DM & $\mathrm{PH}(\mathrm{cm})$ & PP & BY(kg/ha) & GY(kg/ha) & MGY(kg/ha) & DFGY(kg/ha) \\
\hline Habru & $102.75^{c}$ & $57.400^{\mathrm{a}}$ & $78.9^{a b c}$ & $3812.5^{\mathrm{bc}}$ & $1488.8^{c}$ & $1125.00^{b}$ & $1852.5^{\mathrm{ab}}$ \\
\hline Arerti & $118.0^{\mathrm{a}}$ & $55.425^{a}$ & $86.338^{a}$ & $5337.5^{a}$ & $1600.0^{\mathrm{abc}}$ & $1300.00^{\mathrm{ab}}$ & $1900.0^{\mathrm{a}}$ \\
\hline Natoli & $118.1^{\mathrm{a}}$ & $57.975^{a}$ & $85.400^{a}$ & $5118.8^{a}$ & $1837.5^{a}$ & $1475.00^{\mathrm{a}}$ & $2200.0^{\mathrm{a}}$ \\
\hline Ejere & $110.5^{b}$ & $58.688^{a}$ & $69.2^{\mathrm{bc}}$ & $5425.0^{\mathrm{a}}$ & $1556.3^{\mathrm{bc}}$ & $1237.50^{\mathrm{b}}$ & $1875.0^{\mathrm{a}}$ \\
\hline Dalota & $116.3^{a}$ & $58.325^{a}$ & $79.9^{\mathrm{ab}}$ & $4662.5^{\mathrm{ab}}$ & $1818.8^{\mathrm{ab}}$ & $1462.50^{\mathrm{a}}$ & $2175.0^{\mathrm{a}}$ \\
\hline Local & $114.6^{\mathrm{ab}}$ & $42.938^{b}$ & $65.6^{c}$ & $3312.5^{c}$ & $1075.0^{d}$ & $825.00^{c}$ & $1325.0^{b}$ \\
\hline $\mathrm{CV}(\%)$ & 3.94 & 12.92 & 17.05 & 19.45 & 16.92 & 9.504258 & 18.6 \\
\hline $\operatorname{LSD}(0.05)$ & 4.56 & 7.27 & 13.51 & 916.01 & 270.1 & 177.3 & 431.9 \\
\hline
\end{tabular}

*Means with the same letter are not significantly different; $D M=D a y s$ to maturity; $\mathrm{PH}=\mathrm{Plant}$ height; $\mathrm{PP}=\mathrm{Pod}$ per plant; $\mathrm{BY}=\mathrm{Biomass}$ yield; $\mathrm{GY}=\mathrm{Grain}$ yield (kg/ha) of combined;

MGY=Seed yield of Mirab Badwacho; DFGY=Grain yield of damot Fullasa

Table 2: Average values of yield and yield related attributes of chickpea varieties across location and individual districts.

\begin{tabular}{|c|c|c|c|c|c|c|}
\hline \multirow{2}{*}{ Preference Criteria } & \multicolumn{7}{|c|}{ Varieties } \\
\cline { 2 - 7 } & Habru & Arerti & Natoli & Dalota & Ejere & Local \\
\hline Earliness & 1 & 3 & 5 & 3 & 2 & 2 \\
\hline $\begin{array}{c}\text { Disease and pest } \\
\text { resistance }\end{array}$ & 5 & 1 & 2 & 1 & 3 & 4 \\
\hline Seed colour & 1 & 1 & 3 & 3 & 1 & 4 \\
\hline Branch number and length & 2 & 1 & 2 & 2 & 2 & 5 \\
\hline Seed size & 1 & 1 & 2 & 1 & 1 & 4 \\
\hline Grain yield & 3 & 2 & 2 & 2 & 2 & 5 \\
\hline Ground cover & 2 & 1 & 1 & 1 & 1 & 3 \\
\hline Emergence & 2 & 1 & 1 & 1 & 2 & 3 \\
\hline Pod number & 1 & 1 & 2 & 2 & 2 & 5 \\
\hline Seed number & 2 & 1 & 2 & 2 & 2 & 2 \\
\hline Overall score & 21 & 14 & 22 & 18 & 18 & 37 \\
\hline Average score & 2.1 & 1.4 & 2.2 & 1.8 & 1.8 & 3.7 \\
\hline Rank & 4 & 1 & 5 & 3 & 2 & 6 \\
\hline Ranyyyyyyyy
\end{tabular}

NB: "1" means very good and "5" means very poor

Table 3: Shanto Zuria village farmers' variety preference result in Damot Fullassa district of Southern Ethiopia in 2015/2016.

factors kept constant. Similarly, Woybara village farmers' preferred varieties are Natoli, Dalota and Arerti with the mean values of 1.4, 1.7 and 1.9 respectively (Table 4). In the same talken, the yield of Natoli, Dalota, Arerti, Ejere, Habru, and local were $1475 \mathrm{~kg} / \mathrm{ha}, 1462.5 \mathrm{~kg} / \mathrm{ha}$, $1300 \mathrm{~kg} / \mathrm{ha}, 1237.50 \mathrm{~kg} / \mathrm{ha}, 1125.00 \mathrm{~kg} / \mathrm{ha}$ and $825 \mathrm{~kg} / \mathrm{ha}$ in Mihrab Badiwacho woreda of wobera kebele (Table 2). In view of that, chickpea varieties such as Natoli, Dalota, Arerti, Ejere, Habru, and local check were preferred at Mirab Badewacho site (woybra kebele) as $1^{\text {st }}, 2^{\text {nd }}, 3^{\text {rd }}$, $4^{\text {th }}, 5^{\text {th }}$ and $6^{\text {th }}$ respectively.

According to CSA 2014/2015, area in hectares, production in Quintals and yield per hectare of chickpea was 239, 755.25, 4, 586, 822.55, and 19.13 during Meher season in Ethiopia and distribution of area (hectare) under chickpea production in country was shown on

\begin{tabular}{|c|c|c|c|c|c|c|}
\hline \multirow{2}{*}{ Preference Criteria } & \multicolumn{5}{|c|}{ Varieties } \\
\cline { 2 - 7 } & Habru & Arerti & Natoli & Dalota & Ejere & Local \\
\hline Earliness & 1 & 5 & 4 & 3 & 2 & 2 \\
\hline $\begin{array}{c}\text { Disease and pest } \\
\text { resistance }\end{array}$ & 5 & 1 & 1 & 1 & 3 & 4 \\
\hline Seed colour & 3 & 3 & 1 & 2 & 3 & 4 \\
\hline Branch number and length & 4 & 1 & 2 & 2 & 3 & 5 \\
\hline Seed size & 1 & 1 & 1 & 1 & 1 & 4 \\
\hline Grain yield & 4 & 3 & 1 & 2 & 3 & 5 \\
\hline Ground cover & 2 & 1 & 1 & 1 & 1 & 3 \\
\hline Pod number & 1 & 1 & 1 & 2 & 3 & 5 \\
\hline Seed number & 2 & 1 & 1 & 1 & 2 & 2 \\
\hline Overall score & 23 & 17 & 13 & 15 & 21 & 34 \\
\hline Average score & 2.6 & 1.9 & 1.4 & 1.7 & 2.3 & 3.8 \\
\hline Rank & 5 & 3 & 1 & 2 & 4 & 6 \\
\hline
\end{tabular}

NB: "1" means very good and "5" means very poor

Table 4: Wobara village Farmers' variety preference result in Mirab Badewacho district of Southern Ethiopia in 2015/2016.

Figure 1. Similarly, area in hectares, production in Quintals and yield per hectare of chickpea was 5,662.23, 93, 892.80, and 16.58 during Meher (the main season) in SNNPRE [4]. Photos taken during field day farmers PVS demonstration plot evaluation (Figure 2).

Table 5 presented average value of the two districts farmers' preferences for the studied varieties. Accordingly, the two districts farmers' interest of traits combined result indicated that varieties Arerti, Dalota and Natoli are the three best varieties with the average values of $1.65,1.75$ and 1.8, respectively. Researchers and farmers rank comparison are given below (Table 6). Table 6 below revealed that some of farmers' rank did match with researchers rank except for the varieties Natoli and Arerti which was ranked $3^{\text {rd }}$ and $1^{\text {st }}$ by farmers, $1^{\text {st }}$ and $3^{\text {rd }}$ by researchers. The present study confirms farmers' perception about crop 
Citation: Goa Y, Bassa D, Gezahagn G, Chichaybelew M (2017) Farmers Participatory Evaluation of Chickpea Varieties in Mirab Badwacho and Damot Fullasa Districts of Southern Ethiopia. Hydrol Current Res 8: 264. doi: 10.4172/2157-7587.1000264

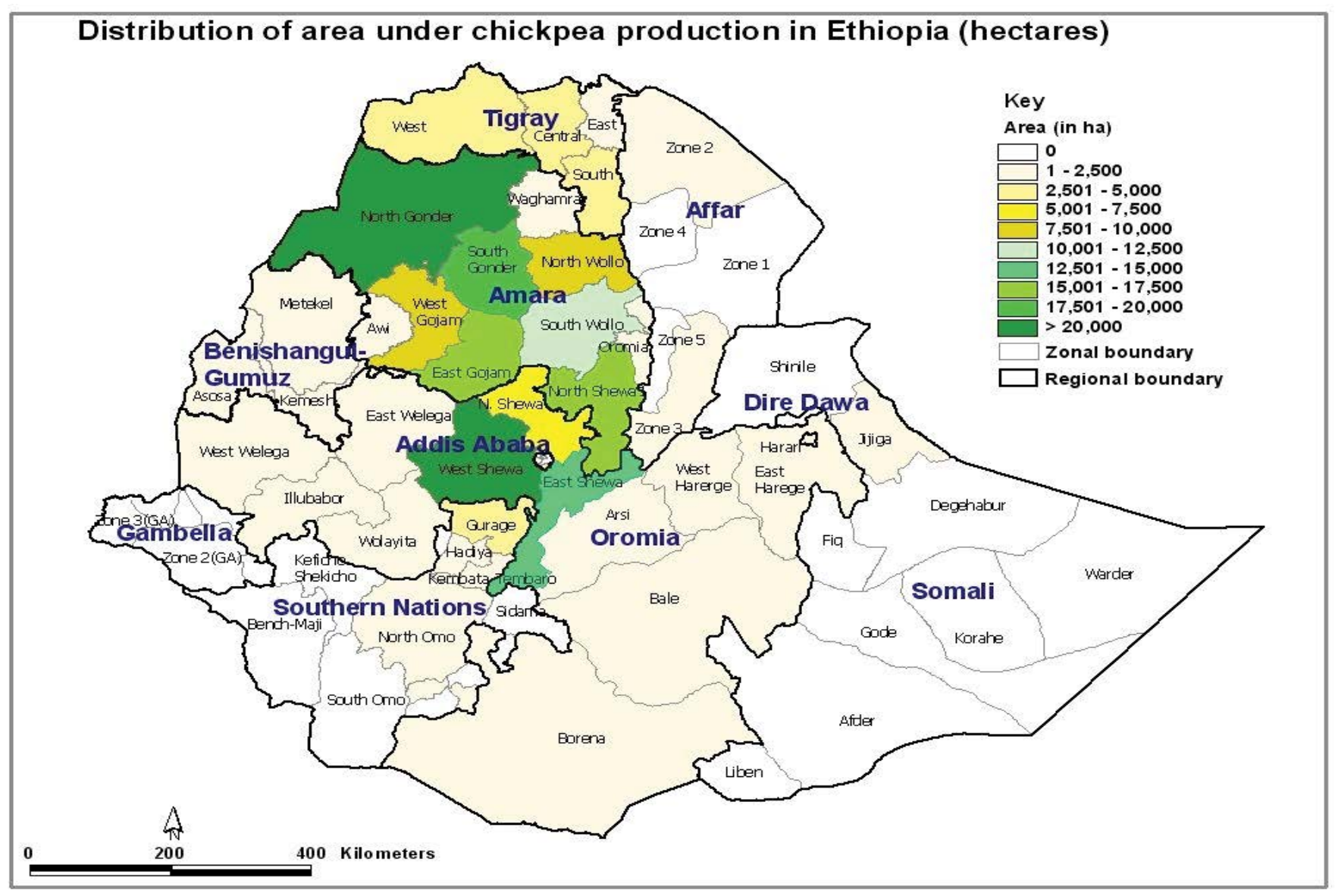

Figure 1: Distribution area of chickpea in Ethiopia [4].
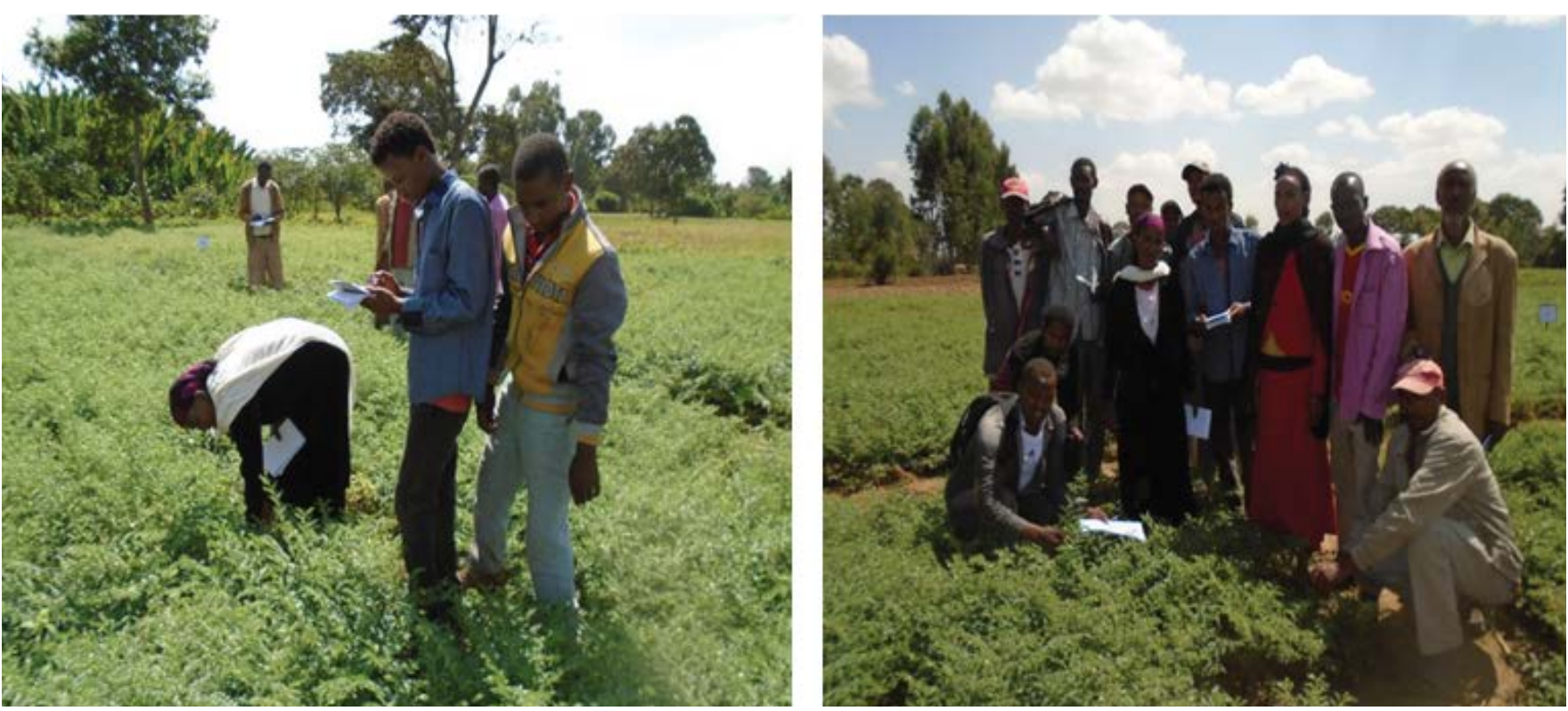

Figure 2: Farmers preferring Chickpea varieties using their preference criteria at flowering stage. 


\begin{tabular}{|c|c|c|c|c|}
\hline Varieties & Damot Fullasa & $\begin{array}{c}\text { Mirab } \\
\text { Badwacho }\end{array}$ & Average & Rank \\
\hline Habru & 2.1 & 2.6 & 2.35 & 5 \\
\hline Arerti & 1.4 & 1.9 & 1.65 & 1 \\
\hline Natoli & 2.2 & 1.4 & 1.8 & 3 \\
\hline Dalota & 1.8 & 1.7 & 1.75 & 2 \\
\hline Ejere & 1.8 & 2.3 & 2.05 & 4 \\
\hline Local & 3.7 & 3.8 & 3.75 & 6 \\
\hline
\end{tabular}

Table 5: Farmers average varietal assessment result in two target districts of Southern Ethiopia (Mirab Badwacho and Damot Fullasa) in Meher season of 2015/2016.

\begin{tabular}{|c|c|c|}
\hline Varities & Researchers rank & Farmers rank \\
\hline Habru & 5 & 5 \\
\hline Arerti & 3 & 1 \\
\hline Natoli & 1 & 3 \\
\hline Dalota & 2 & 2 \\
\hline Ejere & 4 & 4 \\
\hline Local & 6 & 6 \\
\hline
\end{tabular}

Table 6: Chickpea varieties ranking according to farmers and researchers.

varieties are not similar to researchers and if given the chance, farmers are able to express their preferences differently. Though the researchers rank did match with farmers for varieties Habru and Ejere farmers had preferred them as of their early maturity. This is in agreement with Biru et al. $[7,8]$ who stated that there were growing interests among farmers in the use of early chickpea varieties in short rain fall season.

\section{Farmers' field days}

PVS trials by involving 5 released varieties were involved along with farmer' variety as a check, were carried out in Mirab Badewacho (4), and Damot Fullasa (4), and 8 farmers. In total, 2 farmers' field days were organized in target districts of Mirab Badwacho (33; 31 males, 2 females) and Damot Fullasa (62; 56 males, 6 females) with the participation of 99 farmers. Participant farmers were asked to select preferred varieties along with preference criteria during the field days. The choice of parameters that farmers prefer in a variety differs widely from farmer to farmer and area to area. Besides agro ecology, social issues also influence a farmer's selection of crop varieties. The overall analysis from this activity enabled the selection of high yielding released chick pea varieties in respective district and facilitated in designing for further demonstration and scale up strategy. The field day feedback target village farmers indicated that old local varieties were used by farmers because of the absence of alternatives. These varieties are not only low yielding but are highly susceptible to insectpest (pod borer attacks). During the discussions, it was suggested that owing to consecutive years of drought and current Elino event, farmers are looking for early maturing crop varieties which the existing agricultural office and other public agencies are unable to provide. In general farmers' favorite criteria also delivered constructive comments to researchers and development personnel involved in chickpea improvement to devise the research strategy.

\section{Training}

Training on available technologies and socio-economic aspects of chickpea in Ethiopia and southern regions was provided to 49 farmers. A training program was prepared to improve the attentiveness of farmers on chickpea available technology in which 41 farmers (36 males; 5 females at Damot Fullasa), 8 extension personnel $(7$ males, 1 female) also participated. Of the 49 individuals involved in chickpea training, $12 \%$ were women. An information manual was prepared on improved chickpea technologies in Damot Fullasa district in Amharic for development agents.

\section{Awareness activities}

Creation of awareness activities were conducted through FM radio and South television. PVS village training, demonstrations, and farmer field days to share experience were used in awareness creation. In Damot Fullasa, higher officials were involved in awareness creation. Events of all the field days were transmitted on public media (South Television and FM Radio) in Amharic.

\section{Conclusions}

Participatory Varietal Selection (PVS) on chickpea indicated variability of improved varieties preferences among farmers as well as from district to districts. Continuous evaluation of diverse chickpea varieties to substitute local varieties might accelerate the adoption of improved varieties and at the same time maintain genetic diversity of the chickpea. Farmers may require multiple traits from one key crop such as chickpea. However, researchers may not know the traits that are important to farmers and vice versa. Participatory varietal selection has significant role in technology adaptation and dissemination in short time than conventional approach. In these investigation farmers' selection criteria in the two districts were earliness, earliness, Disease and pest resistance, Seed colour, Branch number and length, Seed size Ground cover, Emergence, Pod number, Seed number and grain yield. Based on the criteria they set, their preferred varieties were Natoli, Arerti and Dalota. Researchers also recommend these three varieties for the study area based on the data analysis, agro ecologically suitability and the additional two early maturating chickpea varieties Ejere and Habru were preferred by farmers for double cropping and short rainfall season. Therefore, farmers' varietal selection criteria should be taken into consideration during chickpea improvement programme.

\section{Acknowledgement}

We are grateful to TL-III projects for providing funds for this study. We are very grate to farmers of the Woybara and Shanto Zuria village farmers who made this participatory variety evaluation study possible. Debrezeit Agricultural Research Centre is highly acknowledged for providing the chickpea varieties seeds used for the experiment and active collaborator of our center. We would like to sincerely thank all those who contributed to successful completion of this experiment, especially district agricultural office experts and development agents, Crop Research process owner and Mr Tadel Hirgo, W/rt Bogalech Utta, Mr Deneke Makae, Waza Morgito and Filimon Uliso who are the key role player in conducting the PVS activity and served as technical assistant.

\section{References}

1. http://faostat.fao.org/

2. http://faostat.fao.org/site/567/DesktopDefault.aspx

3. Anbessa Y, Bejiga G (2002) Evaluation of Ethiopian chickpea landraces for tolerance to drought. Genetic Resources and Crop Evolution 49: 557-564.

4. CSA (Central Statistical Agency) (2014/15) Agricultural Sample Survey Report on Area and Production of Crops Private Peasant Holdings, Meher Season.

5. Hulse JH (1991) Nature, composition, and utilization of grain legumes, In: Uses of tropical Legumes: Proceedings of a Consultants' Meeting, 27-30 March 1989, ICRISAT Center, Patancheru, India p: 11-27.

6. Dadi L, Regassa S, Fikre A, Mitiku D, Gaur PM, et al. (2005) Adoption Studies on Improved Chickpea Varieties in Ethiopia. Ethiopian Agricultural Research Organization, Addis Ababa, Ethiopia.

7. Alemu B, Abera D, Adugna A, Terefe M (2014) Adaptation Study of Improved Kabuli Chickpea (Cicer Arietinum L.) Varieties at Kellem Wollega Zone, Haro Sabu, Ethiopia. J Nat Sci Res 4: 21-24.

8. Goa Y (2014) Evaluation of Chick Pea (Cicerarietinum L.) Varieties for Yield Performance and Adaptability to Southern Ethiopia. J Biol Agric Healthc 4: 34-38. 
Citation: Goa Y, Bassa D, Gezahagn G, Chichaybelew M (2017) Farmers Participatory Evaluation of Chickpea Varieties in Mirab Badwacho and Damot Fullasa Districts of Southern Ethiopia. Hydrol Current Res 8: 264. doi: 10.4172/2157-7587.1000264

9. Demelash A, Desalegn T, Alemayehu G (2013) Participatory Varietal Selection of Bread Wheat (Triticum aestivum L.) Genotypes at Marwold Kebele, Womberma Woreda, West Gojam, Ethiopia. Int J Agron Plant Prod 4: 3543 3550 .

10. Gurmu F (2013) Assessment of Farmers' Criteria for Common Bean Variety Selection: The case of Umbullo Watershed in Sidama Zone of the Southern Region of Ethiopia. Ethiopian E-Journal for Research and Innovation Foresight 5: 4-13.
11. Tadesse D, Medhin ZG, Ayalew A (2014) Participatory on Farm Evaluation of Improved Maize Varieties in Chilga District of North Western Ethiopia. Int $J$ Agric Forest 2014 4: 402-407.

12. Danial D, Parlevliet J, Almekinders C, Thiele G (2007) Farmers participation and breeding for durable disease resistance in the Andean region. Euphytica 153: 385-396.

13. Yadaw RB, Khatiwada SP, Chandhary B, Adhikari NP, Baniya B, et al. (2006) Participatory varietal selection (PVS) of rice varieties for rainfed conditions. Rice Fact Sheet, International Rice Research Institute (IRRI). 